ENERGY AND CELLS 
Titles in the Dimensions of Science Series

Energy and Cells C. Gayford

Genes and Chromosomes J. R. Lloyd

Practical Ecology D. Slingsby and C. Cook

Ionic Organic Mechanisms C. Went

Other books by the same author

Study Guides in Human Physiology (with D. G. Mackean)

(published by Murray)

Biology for First Examinations (with A. A. Adams)

(published by Holmes McDougall) 


\section{DIMENSIONS OF SCIENCE}

Series Editor: Professor Jeff Thompson

\section{ENERGY AND CELLS}

\section{Chris Gayford}

Ph.D., M.Ed., B.Sc.

Lecturer in Education

University of Reading

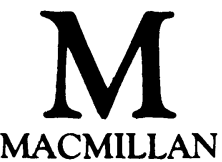


ㄷ C. G. Gayford 1986

All rights reserved. No reproduction, copy or transmission of this publication may be made without written permission.

No paragraph of this publication may be reproduced, copied or transmitted save with written permission or in accordance with the provisions of the Copyright Act 1956 (as amended).

Any person who does any unauthorised act in relation to this publication may be liable to criminal prosecution and civil claims for damages.

First published 1986

Published by

\section{MACMILLAN EDUCATION LTD}

Houndmills, Basingstoke, Hampshire RG21 2XS

and London

Companies and representatives

throughout the world

\section{British Library Cataloguing in Publication Data}

Gayford, Chris

Energy and cells.-(Dimensions of

science series)

1. Cell metabolism 2. Energy metabolism

I. Title II. Series

574.87'61 QH634.5 
To John-Paul, Libby and Claire

\section{Series Standing Order}

If you would like to receive future titles in this series as they are published, you can make use of our standing order facility. To place a standing order please contact your bookseller or, in case of difficulty, write to us at the address below with your name and address and the name of the series. Please state with which title you wish to begin your standing order. (If you live outside the United Kingdom we may not have the rights for your area, in which case we will forward your order to the publisher concerned.)

Customer Services Department, Macmillan Distribution Ltd Houndmills, Basingstoke, Hampshire, RG21 2XS, England. 


\section{Contents}

Series Editor's Preface viii

Preface

Energy - an Introduction $x$

1 Energy 1

2. Adenosine Triphosphate 15

3 Redox Reactions and Cellular Energetics 23

4 Enzymes and Reactions 33

5 Biological Membranes 43

6 Metabolic Pathways of Respiration 64

7 Photosynthesis 99

8 Biosynthesis 125

9 Nerve Impulse Conduction $\quad 139$

10 Muscle Contraction 154

Bibliography and Further Reading 166

Index 168 


\section{Series Editor's Preface}

This book is one in a Series designed to illustrate and explore a range of ways in which scientific knowledge is generated, and techniques are developed and applied. The volumes in this Series will certainly satisfy the needs of students at ' $\mathrm{A}$ ' level and in first-year higher-education courses, although there is no intention to bridge any apparent gap in the transfer from secondary to tertiary stages. Indeed, the notion that a scientific education is both continuous and continuing is implicit in the approach which the authors have taken.

Working from a base of 'common core' ' $\mathrm{A}$ '-level knowledge and principles, each book demonstrates how that knowledge and those principles can be extended in academic terms, and also how they are applied in a variety of contexts which give relevance to the study of the subject. The subject matter is developed both in depth (in intellectual terms) and in breadth (in relevance). A significant feature is the way in which each text makes explicit some aspect of the fundamental processes of science, or shows science, and scientists, 'in action'. In some cases this is made clear by highlighting the methods used by scientists in, for example, employing a systematic approach to the collection of information, or the setting up of an experiment. In other cases the treatment traces a series of related steps in the scientific process, such as investigation, hypothesising, evaluating and problem-solving. The fact that there are many dimensions to the creation of knowledge and to its application by scientists and technologists is the title and consistent theme of all the books in the Series.

The authors are all authorities in the fields in which they have written, and share a common interest in the enjoyment of their work in science. We feel sure that something of that satisfaction will be imparted to their readers in the continuing study of the subject. 


\section{Preface}

\section{CELLULAR ENERGETICS AND EXCHANGES}

The aim of this book is to provide an up-to-date discussion of some of the basic ideas of cell biology and biochemistry appropriate for students who are completing their advanced level studies and who are approaching undergraduate and other comparable courses. A problem faced by many students at this stage is that explanations of some of the basic biochemical and physiological phenomena that are acceptable at GCE A-level, stop significantly short of what is expected in more advanced texts. This book sets out to provide a useful bridge between these two levels.

The topics included are those that are often considered to be difficult by students and teachers alike. Part of the purpose of the book is to reconcile what students may be taught in physical science courses with the biological topics included here, and in this way to provide an intellectually satisfying and coherent view of the subject. Also, it has been the intention to convey something of the way in which science is a growing and developing area of human activity with its own method of enquiry and creative speculation.

Throughout the text an effort has been made to use units and chemical nomenclature accepted by most authorities. Occasionally this has been problematic because some of the older terms are so well established in the literature that a change of name at this stage is likely to cause confusion. Such organic compounds are pyruvate whose new name is 2-oxopropanate, and ketoglutarate which is used in preference to 2-oxoglutarate. 


\section{Energy - An Introduction}

The problem when writing about energy is that there is no satisfactory definition to begin with. Most physics texts start discussions about energy with definitions of work; this can have some helpful things to say to biologists, since work relates to change of energy in a system. In this way there is a concentration on the transfer of energy; however, this is not particularly helpful in thermodynamics but it does focus attention on energy conversion. The idea of the relationship between energy and work is only really helpful in mechanics, and it is a pre-condition in some other processes such as lighting and heating.

Broadly, energy can be said to be the ability of material systems to bring about changes in themselves or the environment. Even this type of statement causes difficulties since it depends on what is meant by 'change'.

The concept of energy shows one of the important characteristics of science in that it is an abstract idea, which although very useful is still only an aid to understanding. When thinking about energy there is a tendency to think of it as a commodity, but really it probably relates to a potential. Thus it is more helpful to think of ways in which energy can be obtained from a system rather than of a body possessing energy.

Really, no simple statements summarising energy are adequate. However, energy is absolutely fundamental to cell physiology and some understanding of its nature and interrelationships in the functioning of cells is essential. Perhaps we can only begin to understand energy through the network of concepts and laws which make up its supporting theories. These relate to the conversion, exchange and conservation of energy and the two laws of thermodynamics. It is the purpose of this short book to throw some light on these associated concepts in a biological context so that students may be able to better understand the relationships that exist between energy and living organisms and the total dependence that life has on energy. Also it is an area of science where impressive discoveries have been made and where researchers have used remarkable ingenuity in order to piece together even the partial picture that we have today. 